\title{
Концепція спряжених на критичній ізохорі циклів Стірлінга, працюючих на двоокису вуглецю
}

\author{
М. В. Швець \\ Одеська національна академія харчових технологій, вул. Канатна, 112, м. Одеса, 65039, Україна
}

В роботі пропонується нова кониепція реалізації цикллу Стірлінга в області не тільки надкритичних, але й, власне, критичних температури і тиску, заснована на виявленій в наших попердніх роботах вираженій гетерогенній структурі надкритичних флюїдів. Існування такої гетерогенної стачіонарної наноструктури решіткового типу в достатньо широких діапазонах надкритичних властивостей, які були названи не-гіббсівською фазою флюїду, було запропановане (Роганковим В.Б та іншими) у рамках моделі ФТ (флуктуаиійної термодинамики). Така флюїдна структура в практичному використанні може бути досить перспективною. Вона проявлясться в наявності досить регулярного, решіткового типу просторового розподілу густини флюїду і його теплових властивостей в т.зв. мезоскопічних малих об'ємах всередині робочих порожнин стискання $і$ розширення пропонованої схеми спряжених стірлінгів. Саме поняття спряження означає ідею максимально-ефективного використання теплоти, одержаної в ичиклі від джерела, иляхом поєднання двох підииклів високого (I) $i$ помірного (II) тиску вздовж критичної ізохори. В роботі введене нове поняття ступеня теплофізичної досконалості (доповнюючий прийняте поняття термодинамічної досконалості, для окремих стадій - ізоліній $і$ вузлів - нод спряжсеного повного ичиклу типу Стірлінга-Рейліса, яке дозволяє кількісно оцінити позитивний ефект додаткової внутрішньої рекуперації на загальну регенерацію теплоти. Ізольована від навколишнього середовища конструкція обох підиіклів (I) i (II) і об `єднуючого стірлінга є його перевагою у порівнянні з ичиками внутрішнього згоряння. В якості потенціальноперспективної робочої речовини пропонується двоокис вуглецю. Таким чином, наша мета полягає у використанні виявлених нанодисперсних властивостей флюїду для формулювання концепиї створення спряженного, досить ефективного ииклу Стірлінга з перспективним робочим тілом - надкритичним двоокисом вуглецю, замість традиџйинго використання водороду або гелію.

Ключові слова: регенерація і рекуперація теплоти, критична ізохора, спряжений цикл Стірлінга, гетерогенна надкритична область.

\section{doi: https://doi.org/10.15673/ret.v55i2.1361}

(C) The Author(s) 2019. This article is an open access publication

This work is licensed under the Creative Commons Attribution 4.0 International License (CC BY)

http://creativecommons.org/licenses/by/4.0/

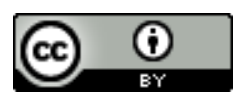

\section{1. Вступ}

Широко поширена думка, що в надкритичній флюїдній (НКФ) області локальні відмінності між щільними та розрідженими фазами стають неможливими. Тобто різке розмежування газ-рідина (2-p)- і рідина-рідина ( $p$-p)-станів, подібне до спостережуваної різниці у фазовому переході першого роду (ФП1) між підкритичною $p$-фазою і підкритичною 2-фазою має повністю зникати. Однак, наші дослідження НФК-станів в рамках моделі ФТ [1-3] дозволили сформулювати нове поняття гетерогенної флуктуаційно термодинамічної (ФТ2)області. Було продемонстровано, що неможливо, наприклад, безперервно трансформувати г-р-стан НКФ в його $p$-p-стан і навпаки - тільки зміною контрольованих $(P, T)$-параметрів, тобто без входу в специфічну ФТ2-область НКФ-фази. Остання відсутня у традиційному гіббсівському ФТ1опису. IIÏ не гіббсівська, тобто гетерогенна, локально-стаціонарна структура виникає, як було нами встановлено до вищої межі зведеного тиску: $\pi_{\max }=P_{\max } / P_{\kappa} \approx 4$. Вона досягається приблизно до зведеної температури $\tau_{\max }=T_{\max } / T_{\kappa} \approx 2$ вздовж критичної ізохори $\omega=\rho / \rho_{\kappa}=1$ для модельної вдВ-рідини. У цій роботі ми стверджуємо, що саме ця відмінна особливість НКФ робить ії дуже привабливою для використання у різноманітних теплових циклах. Альтернативний термін стисливого НКФ-режиму, який використовують інші автори для аналогічних спостережень за явно гетерогенними розподілами густини у цій області парметрів, здається нам не повністю адекватним 


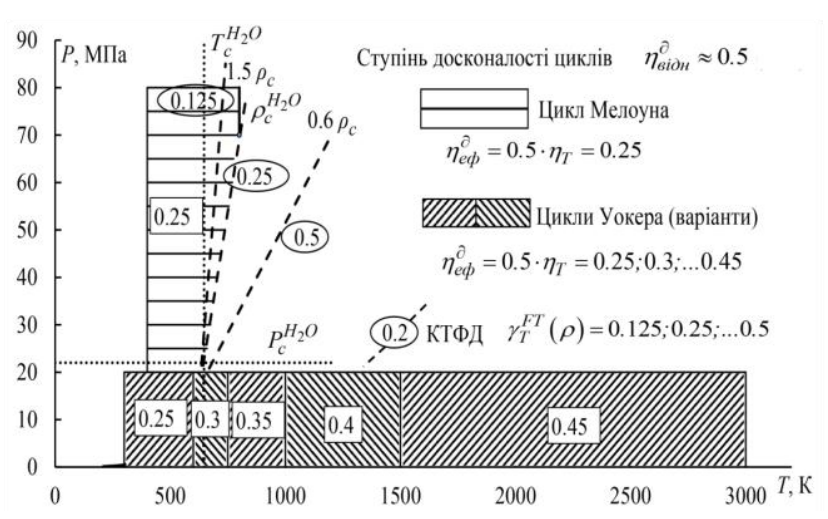

Рисунок 1 - P,T-схема, яка порівнює робочі області альтернативних стірлінгів на воді, введений потім Уокером $\eta_{\text {відн }}^{\partial}=\eta_{\text {еф }}^{\partial} / \eta_{\mathrm{T}} \quad \eta_{\mathrm{Biдн}}^{\mathrm{X}}=\eta_{\mathrm{e \phi}}^{\mathrm{X}} / \eta_{\mathrm{X}}$ і їх ефективні ККД з незалежною оцінкою по КТФД-ізохор в цій роботі.

як раз у знайденій ФТ2-області. Його, треба доповнити важливою для теплоенергетики властивістю дуже швидко транслювати теплову енергію, яка була послідовно доказана в наших роботах. Це доповнення $\epsilon$ необхідним, якщо тепловий двигун повинен бути створений саме для робочої речовини НКФ. Раніше ми запропонували дуже важливу для практики ДВФ (діаграму вибору флюїду) яка буде застосована в даній роботі. Ще в 1930 році Мелоун запропонував модифікований замкнутий цикл Стірлінга на воді, щоб відійти від його стандартної практичної реалізації виключно на дуже легких і низькотемпературних рідинах, таких, як $\mathrm{H}_{2}$, Не або, навіть, повітря [4]. Схема порівняння процесів представлена на Рис. 1. 3 неї видно, що діапазони $\Delta T$ та $\Delta P$ локалізовані в області «твердого» флюїду (тобто за межами псевдоідеальногазового ZL-контуру, що обмежує область т.з. «м'якого» флюїду). На перший погляд, вибір дуже летких газів в якості робочої речовини доцільний, якщо врахувати відомі переваги стандартних теплофізичних коефіцієнтів для легких НКФ порівняно 3 парою $\left(\mathrm{H}_{2} \mathrm{O}\right)$ та/або діоксидом вуглецю $\left(\mathrm{CO}_{2}\right)$. Проте величезна маса і габарити стірлінгів, що працюють на водні $\left(\mathrm{H}_{2}\right)$ і гелію $(\mathrm{He})$, є основними перешкодами для їх більш широкого використання. На жаль, ті самі недоліки є характерними, також для циклу Мелоуна на $\mathrm{H}_{2} \mathrm{O}$.

3 іншого боку, інтенсивний сучасний розвиток і обговорення надкритичних циклів Ренкіна i Брайтона $[5,6]$ для газових турбін базується, перш за всього, на таких робочих рідинах, як $\mathrm{CO}_{2} \mathrm{i} \mathrm{H}_{2} \mathrm{O}$. Таким чином, автори [5] навіть не включили НКФ $\mathrm{H}_{2}$ i Не у довгий список з 35 перспективних НКФ для практичного застосування. Ними було рекомендовано розташувати так званий транскритичний иикл Ренкіна [6] тільки частково у високотемпературній двофазній області ФП1, щоб забезпечити ефективний процес конденсації. Цей транск- ритичний підхід звичайно може бути реалізований, але вищезазначені обмеження, що стосуються також теплового двигуна Стірлінга, здаються занадто важливими. Зокрема, як робоча НКФречовина для стірлінгів, $\mathrm{CO}_{2}$ має очевидні переваги - помірні критичні параметри, стабільне існування рідкої фази, низьку вартість i, навіть, (всупереч розповсюдженої точки зору) відносно невеликий вплив на навколишнє середовище. Отже, широке використання $\mathrm{CO}_{2}$ шляхом розробки, наприклад більш досконалих стірлінгів може підвищити ефективність теплових двигунів і зменшити вплив, що завдає шкоди клімату, який широко обговорюється у зв'язку з проблемою викидів $\mathrm{CO}_{2}$.

Дослідження замкнутих, тобто таких, що не мають безпосереднього контакту з навколишнім середовищем, теплових двигунів з однофазною робочою речовиною представляс собою важливу екологічно і енергетично обгрунтовану альтернативу двигунам внутрішнього згоряння. До таких схем, найчастіше, відносять ідеальний, такий, що складається з двох ізотерм і двох ізохор цикл Стірлінга 3 внутрішньою регенерацією теплоти, класифікований як тип двигунів зовнішнього згоряння. Для них характерна наявність зовнішніх, по відношенню до замкнутої циркуляції робочої речовин, пристроїв (рекуператорів, економайзерів), задачею яких $\epsilon$ підвищення ступеня термодинамічної досконалості циклу (його термічний ККД дорівнює, згідно теореми Карно, ідеальному значенню, яке визначається тільки відмінністю найбільшої і найменшої температур джерела теплоти i охолоджуючого пристрою). В той же час, згадані вище проблемі можливого альтернативного вибору робочої речовини в циклі Стірлінга не приділяється належної уваги, оскільки парадигмою тут $є$ застосування дуже легких і високо-легких надкритичних газів, типу гелію і водню, стиснутих до дуже високих тисків і нагрітих до дуже високих температур. Відомі серйозні недоліки і обмеження їх практичної експлуатації приводять до невиправданого, економічно- i енергетично-витратного методу спроб і помилок при проектування конкретних стірлінгів і вибору області параметрів для їх застосування.

Пропонований нижче т.зв. спряжений цикл Стірлінга створюється двома підциклами високого (I) та помірного (II) тисків, частково розташованих в ФТ2 області для $\mathrm{CO}_{2}$. В роботі пропонується введення додаткової стадії внутрішньої рекуперації теплоти за рахунок інтенсифікації протитечійного розширення-охолодження теплоносія Iпідциклу i стискання нагріву теплоносія IIпідциклу на об'єднуючій їх критичній ізохорі. Всі кількісні оцінки базових ізоліній і вузлів виконані на підставі допущення роботи циклу в заданому інтервалі двох термостатів (тобто важливі але ста- 
ндартно-обговорювані[4-6] питання зовнішнього підведення-відведення теплоти і зовнішньої рекуперації нами не розглядались. В якості моделі для оцінки змінень теплофізичних властивостей використовувалось рівняння стану ван-дер-Ваальса 3 деякими модифікаціями. Спрощена для проведення експрес-аналізу будь-якої речовини ФТметодологія калоричних оцінок буде також запропонована нижче.

\section{2. Конфігурація спряженого надкритичного гетерогенного (СНГ) стірлінга в ДВФ-діа- грамі}

\section{1. Кореляціі принципу відповідних станів (ПВС) і рекомендоване розташування над- критичного гетерогенного стірлінга в НКФ- області}

Наша спроба збільшити внутрішню регенерацію запропонованого СНГ-стірлінга може бути реалізована за допомогою конфігурації двох зв'язаних підциклів I і II, показаних на рис. 2-4. Два протилежні напрямки внутрішньої регенерації в першому (основному) підциклі високого тиску (чорна стрілка вниз) і другому (допоміжному) підциклі помірного тиску (біла стрілка вгору) повинні збігатися 3 критичною ізохорою для використання іiі перспективних ФТ2-властивостей. Такими властивостями є, насамперед, нескінченні значення ізотермічної стисливості, а також ізохорної теплоємності у КТ. Підкреслимо, що ми не збираємося детально порівнювати у цій роботі різні типи циклів i, зокрема, конструкції пристроїв теплопостачання та/або відведення тепла 3 зовнішньої рекуперацією. Замість цього, ми допускаємо, що обидва спряжені I і II підцикли локалізовані між двома загальними тепловими резервуарами з однаковими вищою i нижчою фіксованими температурами: $\tau_{\text {max }} \mathrm{i} \tau_{\text {min }}$, що запобігає досягненню теплової рівноваги в обох. Отже, певна аналогія запропонованого СНГ-стірлінга 3 двох підциклів в НКФобласті з відомим функціонуванням теплової труби, працюючої в межах фіксованої різниці температур але в підкритичному діапазоні параметрів ФП1 стає очевидною. Крім того, ми припускаємо, що вищенаведені висока і низька температури резервуарів можуть бути налаштовані, щоб викликати всередині цих підциклів (i, як наслідок, у сумарному СНГ-стірлінгу) стійку нерівноважну фазу НКФ-переходу.

Строго кажучи, цикл, зображений на Рис. 2-4, $\epsilon$ трохи більш складним, ніж найпростіший ідеальний цикл Стірлінга. Він містить додатково два фрагменти, тобто найбільш високу ізобару $\pi_{\max }$ $3 \rightarrow 4$ (I) i нижню критичну ізобару $\pi_{\text {min }}=\pi=1$. Цикл (II) було введено для забезпечення оптима- льної фіксації заданого діапазону температур: $\Delta \tau=\tau_{\max }-\tau_{\text {min }}$. Таким чином, І-й (основний) підцикл формується нижньою (критичною) ізотермою $1 \rightarrow 2 \quad\left(\tau_{\text {min }}=\tau=1\right)$ псевдо-конденсаційного процесу, щзо знаходиться повністю в межах гетерогенної ФТ2-області. Наступним етапом $\epsilon$ ізохоричне нагрівання-стиснення $2 \rightarrow 3$ при максимально вибраній зведеній густині $\omega_{\max }$. Вона поєднується 3 коротким фрагментом ізобаричного розиирення $3 \rightarrow 4$, щоб точно встановити задану вище температуру на початку ізотермічного процесу, подібного процесу псевдо-випаровування також в гетерогенної ФТ2-області $4 \rightarrow 5$. Теплота, яка споживається робочим НКФ 3 верхнього зовнішнього джерела-резервуара $\tau_{\max }$, призводить до різкого розширювання гіббсівської $p p$-фази і перетворює іiі в кінці $4 \rightarrow 5$ процесу в гетерогенну $n a$ ра-рідинну структуру ФТ2-області. Нарешті, ізохорне розиирення-охолодження $5 \rightarrow 1$, що відбувалося вздовж критичноі ізохори, завершує I-й підцикл саме на місці локалізації КТ для робочої

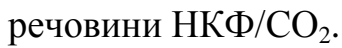

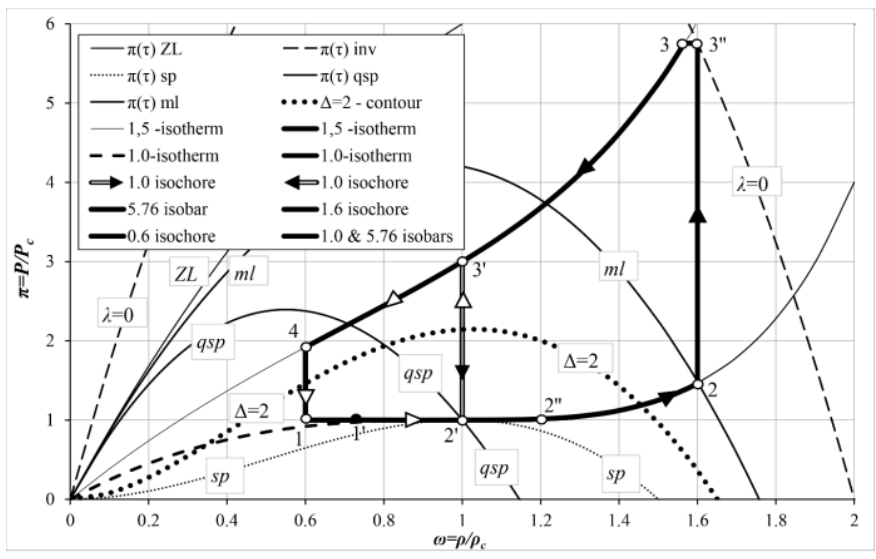

Рисунок 2 - (див. позначення характеристичних ДВФліній). Цикл СГН (спряженого гетерогенного надкритичного) двигуна типу стірлінга-рейліса, утвореного ізотермами ( $\tau=1$ i 1.5$)$, ізохорами ( $\omega=0.6$ і 1.6) і ізобарами ( $\pi=1.0$ і 5.76). Подвійна стрілка при $\omega=1.0$ означає рекуперацію.

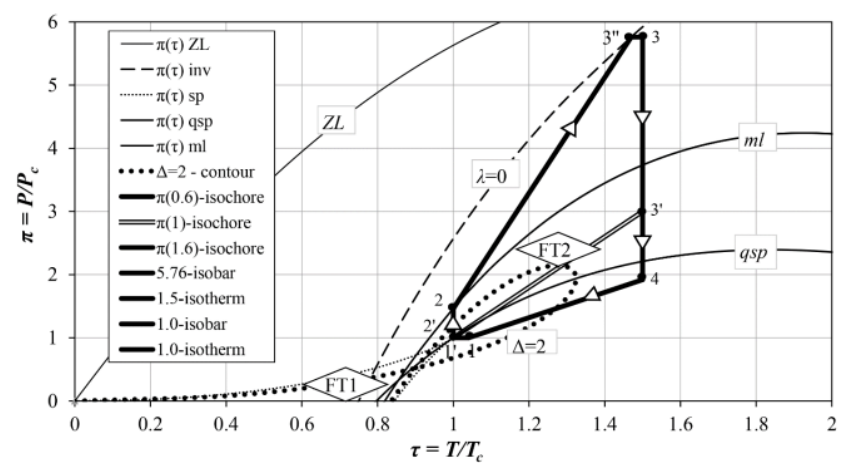

Рисунок 3 - Цикл СГН-двигуна з рекуперацією теплоти вздовж критичної ізохори $\omega=1.0$ (подвійна стрілка), (див. позначення характеристичних ДВФ-ліній). 


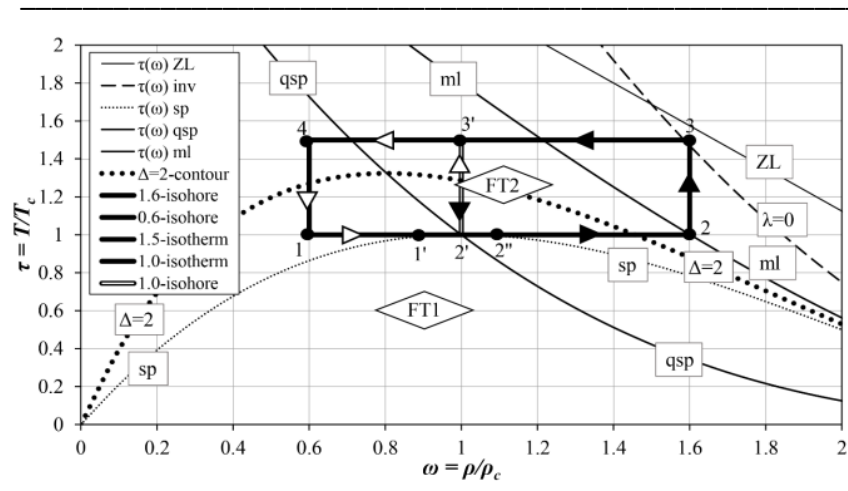

Рисунок 4 - Цикл СГН-двигуна типу стірлінга-рейлісс вироджений в цій $\tau, \omega$-проекції і виглядає, формально як здвоєний (duplex) стірлінг - тепловий насос, відомий в літературі [4], але працюючий в двох діапазонах (гус. тини і тиску), а не температури (див. позначення харак. теристичних ДВФ-ліній)

Поєднання ізохори з ізобарою, подібне до того, що зображено в точках 3 i 7, зазвичай є ознакою так званого циклу Рейліса (або узагальненого циклу Карно) [4]. Однако, тут мається на увазі, що значення такої комбінації в допоміжному II-му підциклі істотно відрізняється від значення в основному І-му підциклі. Щоб пояснити цю відмінність, звернемо увагу на певну топологічну подібність сумарної СНГ-форми циклу з відомим паровим циклом Ренкіна [7], що працює всередині двофазної ФП1-області. Хоча вони належать до різних областей фазової діаграми, обидві мають подібні ізотермічні стадії випаровування та ізотермічної конденсащіï. Обидва вони повинні нібито збігатися 3 відповідними ізотермічно-ізобаричними стадіями. Ця класична концепція ФП1 з підкритичною ізотермою-ізобарою, що існує в межах дво-фазної області між ідеалізованими гіббсівськими 2 - і $p$-фазами, передбачає рівність хімічних потенціалів і гомогенність гіббсівської фази. Це призводить також до теоретичних нескінченностей для вимірюваних $\beta_{T}, \alpha_{P}, C_{P}$-характеристик в будь-якій двофазній си-стемі з кінцевим об'ємом. Ще одним його наслідком $\epsilon$ «знахідка специфічної лінії поділу» Вудкоком [8] на верхньому сегменті кривої співіснування фаз в $(P, \rho)$-площині, розташованій з боку $p$-фази.

$$
\gamma_{H}^{F T}=\frac{P}{T}\left(\frac{d T}{d P}\right)_{H}=\left[\frac{P \delta v}{\delta q}\right]_{H}
$$

Відношення отриманої корисної роботи двигуна до поданого тепла в (1a) та відведеної теплоти охолодження до необхідної роботи у (1б) відповідає умовній ефективності нескінченно малого теплового двигуна $(\mathrm{H})$ і нескінченно малого охолоджувального пристрою (С), відповідно. Обидві вищезазна-
Зауважимо, що з формальної кількісної точки зору важко розрізнити локалізацію критичної ізотерми від критичної ізобари в ФТ2-області, якщо однією 3 координат є ортобарична густина $p$-фази $\rho_{l}(T)$. 3 іншого боку, така різниця форм $P_{c}$ - і $T_{c}$ легко спостерігається ФТ-моделлю з боку г-фази. Дійсно, на рис. 2 показано штриховою лінією, що ортобарична $\rho_{g}(T)$-гілка дійсних $\phi$-систем не відрізняється від критичної ізотерми вдВ-флюїду $\tau=1$. У площині $(P, \rho)$ iї критичний індекс є класичним значенням $\delta_{0}=3$, а передбачуване сплощення некласичної ізотерми $T_{c}$ дає більш високу оцінку значення індексу скейлингу $\delta \approx 9 / 2$. ФТмодель допускає, що така відмінність пов'язана 3 невизначеністю експериментальних критичних ізотермічних даних $P\left(\rho, T_{c}\right)$, отриманих шляхом їх екстраполяції в важковимірюваній області майже критичної г-фази. У будь-якому випадку допоміжний II-й під-цикл складається 3 двох ізохор ( $\omega_{\min }$ i $\omega=1)$, однієї ізотерми $\left(\tau_{\max }\right)$ i однієї (критичної) ізобари $\left(\pi_{\min }=\pi=1\right)$. В результаті запропонований загальний СНГ-стірлінг демонструє формальну схожість 3 циклом Стірлінга-Рейлліса, але його псевдо-конденсаційний процес об'єднується двома критичними сегментами $P_{c}$ - і $T_{c}$-ліній.

\section{2. Запропонована схема СНГ-стірлінга та критерій теплофрізичної досконалості їі ізо- ліній-нод.}

Для зручності читача всі характерні (рекомендовані) вузлові точки, а також зміни параметрів уз-довж ізоліній, показаних на рис. 2-4, представлені в Таблиці 1. Нижче ми припускаємо, що ï значення застосовні також до реальних НКФ. Для отримання комплексних початкових оцінок для подальшого проектування СНГ-стірлінга, що працює на реальних НКФ (розділ 3), ми ввели новий критерій локальної теплофізичної досконалоcmi $\gamma^{F T}$ для прямих $\gamma_{H}^{F T}$ і зворотних $\gamma_{C}^{F T}$ циклів Стірлінга (H - нагрівання - розширення і $\mathrm{C}$ - охолодження - стискання):

$$
\gamma_{C}^{F T}=\frac{T}{P}\left(\frac{d P}{d T}\right)_{C}=\left[\frac{\delta q}{P \delta v}\right]_{C} \quad(\sigma),
$$

чені рівності відносяться до універсального критерію ФТ-моделі $\gamma^{F T}$. Вони безпосередньо, випливають із важливого, але менш відомого (у порівнянні зі звичайною формулою Клаузіуса $(\mathrm{Cl})$ ) формулювання Другого Закону термодинаміки, дуже давно запропонованого Хорстманном (Hr): 


$$
\delta q=\left[T \frac{d P}{d T} \delta v\right]^{H r} \quad \text { (a) } \quad \delta s=\left[\int \frac{d q}{T}\right]^{C l}
$$

Ця надзвичайно глибока формула підкреслює сумісно важливість саме двох параметрів, що підлягають контролю, $(P, T)$ для будь-яких типів перетворення енергії. Це твердження повністю відповідає запропонованому Джоулем поняттю меха- нічного еквівалента тепла. Визначальна роль тиску в динамічних процесах, безумовно, недооцінюється в чисто калоричному формулюванні (2б). Воно базується, однак, на фундаментальному визначенні Клаузіуса щодо поняття оборотної питомої ентpoпіï $s[$ [ж/(кг·К)]. Можливий її вибір як початкової величини для прямого теплофізичного експерименту стартуючи від КТ-положення буде розглянуто в розділі 3.

Таблиця 1 - Параметри вузлових точок та їх зміни уздовж ізоліній

\begin{tabular}{|c|c|c|c|c|c|c|}
\hline$*)$ & knot & $\tau$ & $\pi$ & $\omega$ & \multicolumn{2}{|c|}{$\Delta T=T_{j}-T_{i}, \Delta P=P_{j}-P_{i}, \Delta \rho=\rho_{j}-\rho_{i}$} \\
\hline \multirow{2}{*}{$\mathrm{C} / \mathrm{RG}$} & \multirow{2}{*}{ (I) 1 (II) } & \multirow{2}{*}{1.0} & \multirow{2}{*}{1.0} & \multirow{2}{*}{1.0} & \multirow{2}{*}{$\pi_{\min }=1.0$} & $-\Delta T=0.04 T_{c}[\mathrm{~K}]$ \\
\hline & & & & & & $+\Delta \rho=0.4 \rho_{c}\left[\mathrm{k} \Gamma / \mathrm{M}^{3}\right]$ \\
\hline \multirow{2}{*}{$\mathrm{C}$} & \multirow{2}{*}{ (I) 2} & \multirow{2}{*}{1.0} & \multirow{2}{*}{1.48} & \multirow{2}{*}{1.6} & \multirow{2}{*}{$\tau_{\min }=1.0$} & $+\Delta P=0.48 P_{c}[\mathrm{M \Pi a}]$ \\
\hline & & & & & & $+\Delta \rho=0.6 \rho_{c}\left[\mathrm{k} \Gamma / \mathrm{M}^{3}\right]$ \\
\hline \multirow{2}{*}{ RG } & \multirow{2}{*}{ (I) 3} & \multirow{2}{*}{1.47} & \multirow{2}{*}{5.76} & \multirow{2}{*}{1.6} & \multirow{2}{*}{$\omega_{\max }=1.6$} & $+\Delta T=0.47 T_{c}[\mathrm{~K}]$ \\
\hline & & & & & & $+\Delta P=4.28 P_{c}[\mathrm{M \Pi a}]$ \\
\hline \multirow{2}{*}{ RG } & \multirow{2}{*}{ (I) 4} & \multirow{2}{*}{1,5} & \multirow{2}{*}{5.76} & \multirow{2}{*}{1.55} & \multirow{2}{*}{$\pi_{\max }=5.76$} & $+\Delta T=0.03 T_{c}[\mathrm{~K}]$ \\
\hline & & & & & & $-\Delta \rho=0.05 \rho_{c}\left[\mathrm{kr} / \mathrm{M}^{3}\right]$ \\
\hline \multirow{2}{*}{$\mathrm{H} / \mathrm{RG}$} & \multirow{2}{*}{ (I) 5 (II) } & \multirow{2}{*}{1.5} & \multirow{2}{*}{3.0} & \multirow{2}{*}{1.0} & \multirow{2}{*}{$\tau_{\max }=1.5$} & $-\Delta P=2.76 P_{c}[\mathrm{M \Pi а}]$ \\
\hline & & & & & & $-\Delta \rho=0.55 \rho_{c}\left[\mathrm{kr} / \mathrm{M}^{3}\right]$ \\
\hline \multirow{2}{*}{$\mathrm{H}$} & \multirow{2}{*}{ 6(II) } & \multirow{2}{*}{1.5} & \multirow{2}{*}{1.92} & \multirow{2}{*}{0.6} & \multirow{2}{*}{$\tau_{\max }=1.5$} & $-\Delta P=1.08 P_{c}[\mathrm{M \Pi а}]$ \\
\hline & & & & & & $-\Delta \rho=0.4 \rho_{c}\left[\mathrm{k} \Gamma / \mathrm{m}^{3}\right]$ \\
\hline \multirow{2}{*}{ RG } & $7(\mathrm{II})$ & 104 & 10 & 06 & $0 .=06$ & $-\Delta T=0.46 T_{c}[\mathrm{~K}]$ \\
\hline & (III) & 1.04 & 1.0 & 0.0 & $\omega_{\min }-0.0$ & $-\Delta P=0.92 P_{c}[\mathrm{MПа}]$ \\
\hline
\end{tabular}

*) H -нагрів; C -охолодження; RG - регенерація.

Очевидно, що стандартна диференційна рівність Клаузіуса-Клапейрона, яка отримана 3 постульованого припущення для рівняння вздовж кривої тиску пари $P_{v}(T)$ : для похідних від температури $d \mu_{g}(T)=d \mu_{l}(T)$ є просто конкретною реалізацією рівнянь $(1,2)$ в термінах кінцевих різниць. Ця диференційна рівність застосовується до ідеалізованих повністю зворотних ФП1-процесів, що відбуваються у зоні $v$-фази пари:

$$
\gamma_{v}^{F T}=R i_{v}^{F T} \equiv \frac{T}{P_{v}} \cdot \frac{d P_{v}}{d T}=\frac{\Delta h}{P_{v} \Delta v} .
$$

Відповідний $T$-залежний узагальнений $\Pi B C$ параметр Ріделя: $R i_{v}^{F T}$ був введений раніше у роботах [1-3] по ФТ-моделі. Його термодинамічна когерентність 3 фундаментальним відношенням ентальпії пароутворення $\Delta h=T \Delta s$ до змінення ентропії в ізобаричному процесі ФП1, що виражається як: $\Delta w=P_{v} \Delta v$, була доказана. Вона відповідає, крім то- го, рівності між хімічними потенціалами: $\mu_{g}(T)=\mu_{l}(T)$, як відомо потрібної в макроскопічній термодинаміці при описі ФП1-параметрів.

Поняття мезоскопічних відмінностей між реальними макроскопічними $\phi$-системами кінцевого об'єму і тими (мислимими) в термодинамічному нескінченно-об'ємному обмеженні призводить у ФТмоделі до неминучого розщеплення однієї $P_{v}(T)$ кривої насиченої пари на дві розташовані поблизу одна від одної гілки: $P_{b}(T) \approx P_{v}(T) \geq P_{d}(T)$. Вони утворюють в сукупності проміжну підкритичну фазу (яка називається інтерфазою). ІЇ̈ можна інтерпретувати як альтернативу класичній бінодальній/спінодальній конструкції, створеній в рамках загального $P C$ для г- і $p$-фаз вдВ- типу. Треба підкреслити, що критерії теплофізичноі досконалості, розраховані по НКФ-ізоентропі і НКФ-ізохорі, повинні мати різне значення флуктуацій параметрів порядку і безпорядку (густини та ентропії):

$$
\gamma_{H}^{F T}(s)=\frac{P_{s}}{T}\left(\frac{\partial T}{\partial P}\right)_{s}=\frac{P_{s} \alpha_{P}}{\rho C_{P}} \quad \text { (a) } \quad \gamma_{C}^{F T}(\rho)=\frac{T}{P_{\rho}}\left(\frac{\partial T}{\partial T}\right)_{\rho}=\frac{T}{P_{\rho}} \cdot \frac{\alpha_{P}}{\beta_{T}} \quad \text { (б). }
$$


Вони повинні мати однаковий (позитивний або негативний) знак, що визначається знаком коефіцієнта ізобаричного розширення $\alpha_{P}$. Крім того, обидві рівності, в принципі, необхідні для забезпечення об'єктивного порівняння за $\gamma^{F T}$ критерієм будь-яких циклів у НКФ-області. Тут вони можуть бути легко перетворені у відомі рівності Еренфеста для кінцевих різниць для ФТ2:

$$
\gamma_{H}^{F T}\left(s_{c}\right)=\frac{P_{s} \Delta \alpha_{P}}{\rho \Delta C_{P}} \quad \text { (a) } \quad \gamma_{C}^{F T}\left(\rho_{c}\right)=\frac{T}{P_{\rho}} \cdot \frac{\Delta \alpha_{P}}{\Delta \beta_{T}}
$$

Наша увага буде зосереджена нижче на особливої ролі відомого 3 термодинаміки незворотного ефекту Джоуля-Томпсона. Цій-коефіцієнт і його знак найбільш безпосередньо пов'язані, як відомо, 3 проблемою внутрішньої регенерації в стірлінгах i, зокрема, 3 проблемою будь-яких НКФ-процесів, загалом:

$$
\left(\frac{\partial T}{\partial P}\right)_{h} \equiv-\left(\frac{\partial h}{\partial P}\right)_{T} /\left(\frac{\partial h}{\partial T}\right)_{P}=\frac{T\left(\alpha_{P}-\alpha_{P}^{i g}\right)}{\rho C_{P}} .
$$

Він визначається як ізоентальпійна зміна контрольованої температури по відношенню до регульованого тиску. Таким чином, знак його локального $\lambda$ значення повністю залежить від знаку ізобаричного розширення $\alpha_{P}\left(\alpha_{P}^{i g}=1 / T ; Z R / M=P / \rho T\right)$ :

$$
\gamma_{H}^{F T}(h) \equiv \frac{P_{h}}{T} \cdot\left(\frac{\partial T}{\partial P}\right)_{h}=\frac{Z R}{M} \cdot \frac{\beta_{T} \lambda}{C_{P}} \gtrless 0,
$$

де $\lambda=-\beta_{T}^{-1}+T \cdot \gamma_{\nu}$. Це представлення зведеного ізоентальпійного коефіцієнта Джоуля-Томпсона за рівняннями $(6,7)$ можна порівняти 3 ізоентропійними рівняннями $(4 \mathrm{a}, 5 \mathrm{a})$, щоб пояснити основну ідею запропонованого у цій роботі терміну ФТ2. 3 порівняння (6) з (4а) випливає, що єдиною формальною відмінністю між необоротністю попереднього і оборотністю останнього є локальна різниця коефіцієнтів ізобаричного розширення $\left(\alpha_{P}-1 / T\right)$ і $\alpha_{P}$, відповідно. Отже, рівняння (5а) для кінцевої різниці Еренфеста для ФТ2 в НКФ-області повинно додатково включати флуктуаційну корекцію падіння температури: $\Delta \alpha_{P}^{i g}=\Delta(1 / T)$ щоб імітувати реалістичну ізоентальпійну зміну параметрів. Варто зазначити, що подібна трансформація типу запропонованого Еренфестом стандартного ізоентропного індексу $\gamma_{s}=-(v / P)(\partial P / \partial v)_{s}=1 /\left(P \beta_{s}\right)$ призводить також до флуктуаційної корекції - падіння тиску $\Delta \beta_{T}^{i g}=\Delta(1 / P)$ для зміни ентальпіі:

$$
\gamma_{s} \approx-\frac{v}{P} \cdot \frac{\Delta_{s} P}{\Delta_{s} v}=\frac{1}{P \beta_{T}} \cdot \frac{C_{P}}{C_{v}} .
$$

Його очікуване $i g$ - (ідеальний газ) співвідношення $\gamma_{s}^{i g}=\left(C_{P} / C_{v}\right)^{i g}$ може бути отримано тільки детерміністичним $i g$-представленням $\Delta$-флуктуацій $\left(P \beta_{T}\right)^{i g}=1$.

Всі вищезазначені ФТ-кореляції мають велике значення для забезпечення термодинамічноузгодженого опису процесу регенерації. Для переважної більшості стірлінгів [4] вони реалізуються в пористих середовищах як пристрої в кінцевомірному описі незворотних адіабатичних (тобто неізоентропних) процесів. Термін внутрішній рекуператор може бути віднесений як раз до запропонованого нами СНГ-стірлінга. За змістом це еквівалентне протитечійному теплообміннику, утвореному двома спареними регенераторами I-го і II-го підциклів. Обидва іiі регенеративні компоненти повинні діяти окремо як звичайні регенератори у відповідних циклах. Одночасно, їх локалізація вздовж критичної ізохори $\omega=1$ має забезпечити інтенсифікацію нагрівання не тільки при ізохорному стисканні $2 \rightarrow 3$ (I), але і при ізохоричному стисканні $1 \rightarrow 5$ (II). Для останнього процесу теплоємності різко знижуються як функція температури вздовж критичної ізохори. Це показано на рис. 5 для $\mathrm{CO}_{2}$-типу речовини $\left(i=6,\left(C_{P} / C_{v}\right)=4 / 3\right)$.

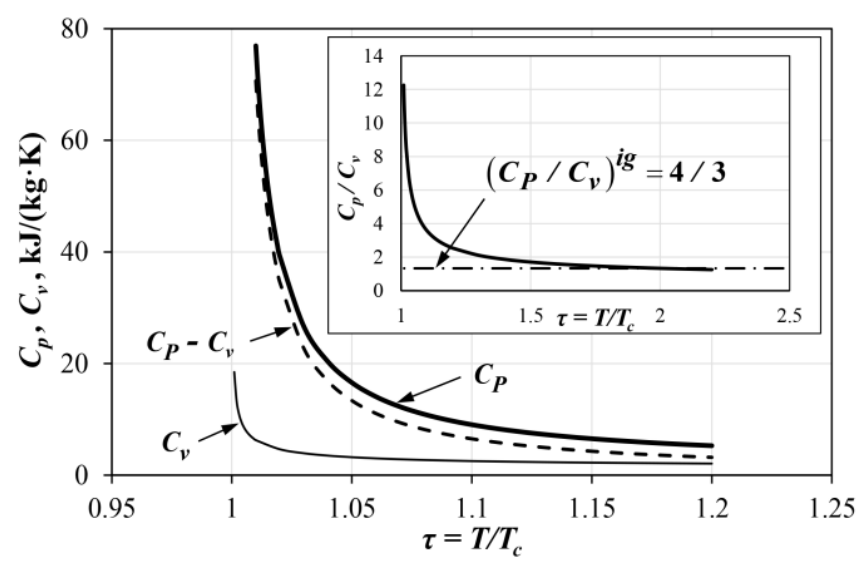

Рисунок 5 - Поведінка теплоємностей на критичній iзохорі $\rho_{\kappa}=468$ кг/ $\mathrm{m}^{3}$ для $\mathrm{CO}_{2}$.

\section{3. Калоричні діаграми і їх вплив на конвек- ційний потік СНГ-циклу}

\section{1. Нерівноважна флуктуаційна форма ФТ- PC}

Формулювання Другого Закону Хорстманном (2a) забезпечує можливість усунення прямого застосування ентропії Клаузіуса (2б) при описі Першого закону для замкнутої $\phi$-системи. Вона також вказує шлях для отримання так званого диференційного термодинамічного РС для двофазних станів: 


$$
P=T \frac{d P}{d T}-\frac{\Delta e}{\Delta v} \approx T \frac{d P}{d T}-P_{i n t},
$$

де друга наближена рівність визначає внутрішній тиск $P_{i n t}$. Останній зв'язаний з поняттям теплофізичної досконалості $\gamma_{v}$, який додається до т.зв. теплового тиску. Іншою надзвичайною особливістю рівняння (9) $є$ рівноцінна застосовність до співвідношення похідних в однофазних станах:

$$
P=T\left(\frac{\partial P}{\partial T}\right)_{v}-\left(\frac{\partial e}{\partial v}\right)_{T} \equiv T\left(\frac{\partial P}{\partial T}\right)_{v}+\left(\frac{\partial e}{\partial \rho}\right)_{T} \cdot \rho^{2}
$$

Таким чином, як Перший, так і Другий закони при описі нерівноважних ефектів беруть участь у визначенні змін параметрів універсального РС. Вони можуть бути як однорідними згідно з формулою

$$
a_{f}(T)=-\left(\frac{\partial e}{\partial \rho}\right)_{T} \quad(a)
$$

Звичайно, обидві $f$-залежні форми рівняння (11) треба вважати строго еквівалентними рівнянням (9) i (10) у вигляді:

$$
P_{v}=T \frac{d P_{v}}{d T}+\rho_{l} \rho_{g} \frac{e_{l}-e_{g}}{\rho_{l}-\rho_{g}} .
$$

Саме ці відповідності використовувалися ФТмоделлю для виведення $T$-залежних $\phi$-коефіцієнтів без будь-яких підгінних параметрів. Щоб проілюструвати очевидні переваги ФТ-методології при аналізі циклів, ми використали у цій роботі суттєво спрощені вдВ-кореляції з постійними $(a, b)$ коефіцієнтами для всіх калоричних функцій:

$$
\begin{gathered}
s_{2}-s_{1}=\frac{i}{2} \frac{R}{M} \ln \left(\frac{T_{2}}{T_{1}}\right)+\frac{R}{M} \ln \frac{v_{2}-b}{v_{1}-b}, \\
e_{2}-e_{1}=\frac{i}{2} \frac{R}{M}\left(T_{2}-T_{1}\right)-\frac{a}{v_{2}}+\frac{a}{v_{1}}, \\
h_{2}-h_{1}=\frac{i}{2} \frac{R}{M}\left(T_{2}-T_{1}\right)-\frac{2 a}{v_{2}}+\frac{2 a}{v_{1}}+\frac{R T_{2}}{M \varepsilon_{2}}-\frac{R T_{1}}{M \varepsilon_{1}} .
\end{gathered}
$$

При описі пористих середовищ та типових регенераторів теплоти, у тому числі, праметр $\varepsilon_{f}=[(v-b) / v]_{f} \equiv 1-(b \rho)_{f}$ було названо параметром специффічної ф-пористості. Тобто це є характеристика зменшення наявного питомого об'єму, визначеного в будь-якому $\phi$-стані, якщо прийняти в (14-16) ідеально-газове іг-припущення: $C_{v}=(i R) / 2 M=$ const . "Іерархія" рівнянь (14-16), що виникла внаслідок лінійності вдВ-РС в змінній $T$, грає істотну роль у пропонуємих нижче СНГрекомендаціях. Перші $T$-залежні внески в ці рівняння $є$ такими, як для іг-моделі. Це можна використовувати в традиційному теплоенергетичному аналізі [4]. Однак другий густино- або v-залежний внесок
(10) та/або неоднорідними згідно з формулою (9).

Ці факти використовувались у ФТ-моделі для розробки загальної 3-коефіцієнтної форми ФТ-РС 3 $T$-залежними коефіцієнтами:

$$
Z_{f}^{F T}-1=\frac{b_{f}(T) \rho-c_{f}(T)}{1-b_{f}(T) \rho}-\frac{a_{f}(T) \rho}{k_{B} T} .
$$

Флуктуаційний та $T$-залежний коефіцієнт $c_{f}(T)$ описує відхилення, в сенсі теорії збурень, від узагальненого $T$-залежного РC ван-дер-Ваальса. Внесок сили когезї до внутрішнього тиску $P_{i n t}$ має зовсім інше значення в співіснуючих $\phi$-фазах. Це було враховано в ФТ-моделі узагальненим вдВкоефіціснтом, $a_{f}(T)$ пов'язаним 3 параметром Ріделя $R i_{v}^{F T}$ з рівняння (3):

$a_{v}(T)=-\frac{e_{l}-e_{g}}{\rho_{l}-\rho_{g}}=\frac{P_{v}\left(R i_{v}^{F T}-1\right)}{\rho_{l} \rho_{g}} \quad$ (б).

(де $b €$ виключений об'єм) - має ефект для ентропії $s(T, \rho)$, як і $a$ (сила когезіi) - має ефект для внутрішньої енергії $e(T, \rho)$, i, нарешті, обидва $(a, b)$ коефіцієнти мають вплив на ентальпію $h(T, \rho)$. Це просте твердження є досить актуальним для введення фізично-обгрунтованих факторів оптимізації для будь-якого реального циклу.

Важливий ФТ-коефіцієнт оптимізації процесів у циклі може бути визначений співвідношенням внутрішньо-енергетичної різниці $\Delta e \equiv e_{2}-e_{1}$ до різниці ентальпії, для кожного довільного сегмента циклу $\Delta h \equiv h_{2}-h_{1} 1 \rightarrow 2$ :

$$
\delta_{i j}=\frac{\Delta e}{\Delta h} \approx \frac{\delta q-\delta w}{\delta q} .
$$

Друга наближена рівність застосовна як до кінцевих на інтервалі часу рівноважних, так і до нерівноважних змін термодинамічних параметрів без обмежень при визначенні вхідного квазірівноважного тепла: $\Delta h=T \Delta s$ і вихідноі квазірівноважноі роботи: $\Delta w=P_{v} \Delta v$. Отже, менша величина коефіцієнта $\delta_{i j}$ не $є$ обов'язково еквівалентною більш високій ефективності цього сегмента $i \rightarrow j$. Введений за допомогою (17) ФТ-коефіцієнт оптимізації корисний, насамперед, для оцінки загального балансу кожної калоричної функції (див. Табл. 2) для всього циклу або його замкнутого підциклу. Чим менше абсолютна величина загального балансу, тим ефективніше реалізація відповідного циклу на практиці.

Друге застосування ФТ-коефіцієнта оптимізаціï, зв'язаного з $\delta$-факто-ром, може використовуватись для спрощення рішення найскладнішої теоретичної задачі стірлінгів щодо динамічних нестаціонарних стадій циклу. В усталеній, досить складній 
методології аналізу окремих нод циклу [4,7] ставиться наступна загальна проблема. За стандартними чисельними методами необхідно інтегрувати систему нелінійних рівнянь балансу маси, імпульсу і внутрішньої енергії (або ентропії), доповнених системою транспортних квазілінійних градієнтних законів і вибраним тепловим РС робочої речовини. Всі складності такого традиційного підходу добре відомі і широко обговорюються в теплоенергетиці. Альтернативний шлях до розв'язання може розглядатися, якщо відповідне конвективне одновимірне поле швидкості механічного потоку $\vec{u}(\vec{x}, t) \in$ надійно визначеним для окремих сегментів загального контуру. Нагадаємо, що відповідно до спрощеного закону Бернуллі для стаціонарного, ламінарного, нев'язкого і нестисливого потоку його швидкість стає меншою, якщо тиск зростає. В результаті, обидва основні динамічні тренди циклу це - 1) уповільнення потоку при його стисненні і 2) прискорення потоку при його розширенні. Обидві протилежні одна одній стадії добре відокремлені одна від іншої. Зрозуміло, що вплив вихідних та/або вхідних температурних змін на вищевказані тиски стиснення та/або розширення має вирішальне значення для проектування замкнутих контурів стірлінгів. Регенерація тепла $є$ необхідним в певному сенсі інструментом для налаштування відповідного стаціонарного режиму потоків робочої речовини. Проте головний висновок про конкретне поле швидкостей залишається незмінним, навіть якщо в повній мірі врахувати процес передачі тепла, маси та імпульсу за допомогою узагальненого закону Бернуллі. Цей результат дає принципову можливість при проектуванні надійно оцінювати значення конвективної швидкості для різних сегментів СНГ-циклу на основі виключно змін, що наведені в Таблиці 2 (тобто без інтеграції вищезазначеної складної системи нелінійних рівнянь). Така інформація може бути суттєво важливою для розвитку та подальшої оптимізації реального циклу.

Таблиця 2 - Зміна калоричних функцій вдВ-функцій, розрахованих за формулами (14-17) для всього циклу СНГ (a) та його підциклів I та II (b).

а) - весь СНГ-цикл

\begin{tabular}{|l|c|c|c|c|}
\hline Сегмент (a) & $\Delta s, \mathrm{k}$ Дж/(kг $\cdot \mathrm{K})$ & $\Delta e, \mathrm{k}$ Дж/kг & $\Delta h, \mathrm{k}$ Дж/kг & $\delta=\Delta e / \Delta h$ \\
\hline $1 \rightarrow 2 ; T_{\min }=T_{c}$ & -0.156 & -38.7 & -39.9 & 0.97 \\
\hline $2 \rightarrow 3 ; \rho_{\max }=1.6 \rho_{c}$ & +0.218 & +80.9 & +123.1 & 0.66 \\
\hline $3 \rightarrow 4 ; P_{\max }=5.76 P_{c}$ & +0.024 & +8.3 & +10.1 & 0.82 \\
\hline $4 \rightarrow 6 ; T_{\max }=1.5 T_{c}$ & +0.274 & +61.4 & +53.3 & 1.15 \\
\hline $6 \rightarrow 7 ; \rho_{\min }=0.6 \rho_{c}$ & -0.207 & -79.1 & -103.4 & 0.76 \\
\hline $7 \rightarrow 1 ; P_{\min }=P_{c}$ & -0.153 & -32.6 & -43.2 & 0.76 \\
\hline$\Sigma=| \pm \Sigma|$ & 0.516 & 150.4 & 186.5 & 0.81 \\
\hline
\end{tabular}

б) - головний підцикл I СНГ

\begin{tabular}{|c|c|c|c|c|}
\hline Сегмент (Іб) & $\Delta s, \mathrm{k} Д ж /(\mathrm{k} \Gamma \cdot \mathrm{K})$ & $\Delta e, \mathrm{k} Д ж / \mathrm{k} \Gamma$ & $\Delta h, \mathrm{k} Д ж / \mathrm{k} \Gamma$ & $\delta=\Delta e / \Delta h$ \\
\hline $1 \rightarrow 2 ; T_{\text {min }}=T_{c}$ & -0.156 & -38.7 & -39.9 & 0.97 \\
\hline $2 \rightarrow 3 ; \rho_{\max }=1.6 \rho_{c}$ & +0.218 & +80.9 & +123.1 & 0.66 \\
\hline $3 \rightarrow 4 ; P_{\max }=5.76 P_{c}$ & +0.024 & +8.3 & +10.1 & 0.82 \\
\hline $4 \rightarrow 5 ; T_{\max }=1.5 T_{c}$ & +0.143 & +35.5 & +24.3 & 1.46 \\
\hline $5 \rightarrow 1 ; \rho_{\text {min }}=\rho_{c}$ & -0.229 & -86.0 & -117.6 & 0.73 \\
\hline$\Sigma_{(I)}=| \pm \Sigma|$ & 0.385 & 124.7 & 157.5 & 0.79 \\
\hline
\end{tabular}

б) - допоміжний підцикл II СНГ

\begin{tabular}{|c|c|c|c|c|}
\hline Сегмент (ІІб) & $\Delta s, \mathrm{k} Д ж /(\mathrm{k} \Gamma \cdot \mathrm{K})$ & $\Delta e, \mathrm{k} Д ж / \mathrm{k} \Gamma$ & $\Delta h, \mathrm{k} Д ж / \mathrm{k} \Gamma$ & $\delta=\Delta e / \Delta h$ \\
\hline $1 \rightarrow 5 ; \rho_{\max }=\rho_{c}$ & +0.229 & +86.0 & +117.6 & 0.73 \\
\hline $5 \rightarrow 6 ; T_{\max }=1.5 T_{c}$ & +0.131 & +25.9 & +29.0 & 0.89 \\
\hline $6 \rightarrow 7 ; \rho_{\text {min }}=0.6 \rho_{c}$ & -0.207 & -79.1 & -103.4 & 0.76 \\
\hline $7 \rightarrow 1 ; P_{\min }=P_{c}$ & -0.153 & -32.6 & -43.2 & 0.76 \\
\hline$\Sigma_{(I I)}=| \pm \Sigma|$ & 0.360 & 111.7 & 146.6 & 0.76 \\
\hline
\end{tabular}


3.2. Порівняння СНГ-Стірлінга 3 циклом Брайтона за спрощеною ФТ-методологією побудови калоричної діаграми для замкнених циклів.

Будь-який порівняльний аналіз ефективності реального циклу (він базується на так званому термічному ККД або ідеальному коефіиієнті ефективності $\eta=1-T_{C} / T_{H}$ ) має бути узгодженим 3 Другим Законом. Його зведене, більш реалістичне значення, називається ефективним коефіиіснтом термодинамічної досконалості) $\eta_{e} \lesssim 0.5 \eta_{T}$. Такий підхід потребує об'єктивного «інструменту» для порівняння різних впливових факторів на циклічний процес. Калорична $(T, s)$-діаграма надає, принаймні, найбільш корисну інформацію для цієї мети $[4,7]$, але іiі обмеження також очевидні і мають бути зазначені.

Значення питомої ентропії $s(T, \rho)$ та інших питомих калоричних функцій $e(T, \rho), h(T, \rho)$ повинні бути універсально узгоджені і з Третім Законом. Ця вимога не виконується в багатьох практичних застосуваннях [5,6] на основі як термічних, так і фундаментальних РС. Вибір, наприклад, для води, ну-

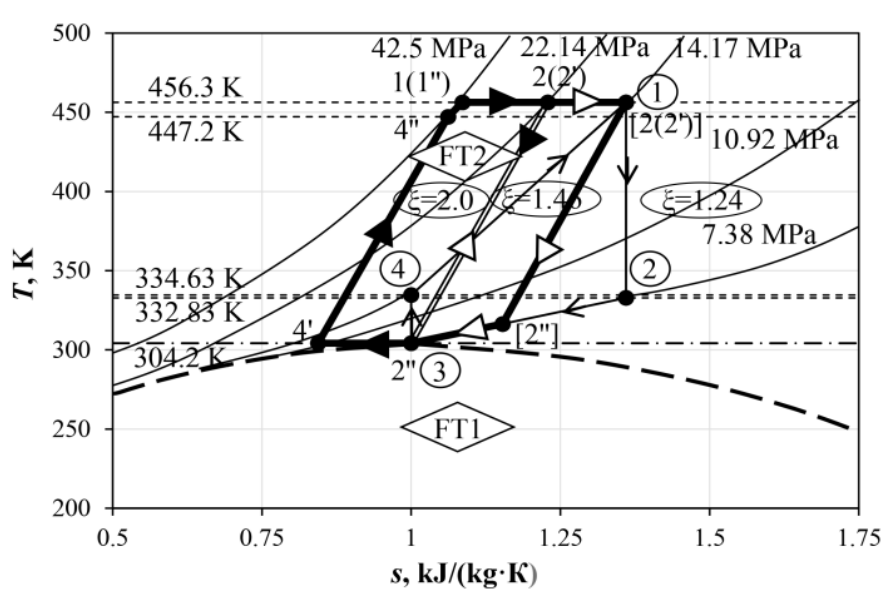

Рисунок 6 - $(T, s)$-діаграма СГН-циклу для двоокису вуглецю, побудована по вузлових точках $\left(s_{\kappa}=1.0\right.$ кДж/(кг·К)) для вдВ-флюїду і iї порівняння 3 трьома варіантами циклу Брайтона для $1 \rightarrow 2 \rightarrow 3 \rightarrow 4 \rightarrow 1$ надкритичної газової турбіни (див. текст).

льової величини ентропії насиченої рідини $s_{l}\left(T_{t}, P_{t}\right)=0$, при температурі потрійної (або плавлення) точки і ї̈ незначного тиску не $є$ повністю узгодженим. ФТ-методологія пропонує спрощений і досить мотивований вибір калоричних параметрів, виходячи з постульованих рівняннь, саме у КТ:

$$
s_{c}=1.0 \mathrm{k} Д ж /(k 2 \cdot K) ; \quad \mu_{c}=h_{c}-T_{c} s_{c}=0 .
$$

Теоретичною перевагою такої $s_{c}$ універсальності, прийняятої в ФТ-моделі для всіх чистих ре- човин, є розгляд реальних процесів більш реалістичними (експериментально-вимірними) незворотними змінами калоричних функцій $e(v, T)$ i $h(T, P)$.

Навпаки, вся класична теорія ФП1 грунтується на концепції рівноважної оборотності, що регулює еквівалентність $(p \rightarrow c)$ і $(2 \rightarrow p)$-переходів $\left(\Delta_{g} h=-\Delta_{g l} h\right)$ між двома рівноважними станами г і $p$.

Відхилення реального адіабатичного стиснення і розширення від їх ізоентропних «аналогів» в ідеальному циклі Брайтона виникають внаслідок термодинамічної незворотності. У першу чергу, неминучі перепади тиску під час додавання тепла до робочої рідини і відведення тепла від неї є супутніми явищами тієї ж фізичної причини. Проте перший фактор формально збільшує значення ідеальної ефективності $\eta_{T}$, тоді як останній фактор суттєво зменшує його.

Існують два основних типи циклів Брайтона: 1) газові турбіни працюючі на відкритому контурі, який нагрівається безпосередньо за допомогою камери згоряння; 2) замкнутий контур, який нагрівається опосередковано за допомогою теплообмінника (нагрівача). Природно, що нижче запропонований СНГ-стірлінг можна порівняти тільки з останнім варіантом циклу Брайтона. Він може бути реалізований або при зовнішній рекуперації тепла, як у напівзакритому енергетичному циклі $\mathrm{HK \Phi} / \mathrm{CO}_{2}$, так і без власної регенерації тепла, подібної тій, що застосовується в циклах Стірлінга та/або Еріксона. Типова температура і тиск [4,5] можуть становити до $1000 \mathrm{~K}$ і $30 \mathrm{MПа,} \mathrm{відповідно,} \mathrm{для} \mathrm{непрямо-}$ нагрітого замкнутого циклу Брайтона на $\mathrm{CO}_{2}$, тоді як до $1500 \mathrm{~K}$ і 30 МПа для прямо- нагрітого його варіанта на $\mathrm{CO}_{2}$. У той же час типові умови роботи стірлінгів на робочих рідинах $\left(\mathrm{He}, \mathrm{H}_{2}\right)$ можуть становити до $900 \mathrm{~K} \mathrm{і} \mathrm{до} 40$ МПа, відповідно. Таке порівняння призводить приблизно до сумісних оцінок ідеальної ефективності $\eta_{T}^{B} \approx 2 / 3$, якщо загальноприйнята мінімальна температура обох (Брайтона i Стірлінга) циклів прийнята приблизно рівною: $T_{C}=300 \mathrm{~K} \approx T_{c}\left(\mathrm{CO}_{2}\right)$. Вірогідна оцінка ефективної термодинамічної досконалості повинна бути приблизно такою: $\eta_{e}^{B} \approx 1 / 3$ (або менше) в цьому випадку. Основною метою порівняння циклів, проілюстрованого на рис. 6, є обгрунтування набагато більш високого рівня термодинамічної досконалості, досяжної для СНГ-стірлінга. Вона веде без додаткового збільщення максимального $T_{H}$-значення до аналогічного реалістичного значення: $\eta_{e}^{C S H} \approx 0.9 \cdot \eta_{T}^{C S H}=0.3$. Одночасно, може бути отримано набагато більше значення так званої відносної питомої (на одиницю маси) потужності двигуна $\xi$ [1] внаслідок значного 
Таблиця 3 - Вхідні КП-параметри ФТ-методології представлені для діоксиду вуглецю, води і аргону (для порівняння).

\begin{tabular}{|c|c|c|c|c|c|c|}
\hline Fluid & $T_{c}, \mathrm{~K}$ & $P_{c}$, МРПа & $\rho_{c}, \mathrm{k} \Gamma / \mathrm{M}^{3}$ & $s_{c}, \mathrm{k}$ Дж/(kг·K) & $h_{c}, \mathrm{k}$ Дж/kг & $e, \mathrm{k}$ Дж/kг \\
\hline $\mathrm{CO}_{2}$ & 304.2 & 7.38 & 468 & 1.0 & 304.2 & 288.4 \\
\hline $\mathrm{H}_{2} \mathrm{O}$ & 647.1 & 22.06 & 322 & 1.0 & 647.1 & 578.6 \\
\hline $\mathrm{Ar}$ & 150.7 & 4.86 & 531 & 1.0 & 150.7 & 141.5 \\
\hline
\end{tabular}

збільшення максимального тиску в СНГ-стірлінгу: $P_{\max }=42.5$ МПа:

$$
\xi \approx\left(P_{\max }+P_{\min }\right) / 2 P_{\min }
$$

Її більш детальна оцінка часто занадто складна навіть для занадто простих іг-циклів [4].

Отже, ми використали спрощену формулу (19) для розрахунку трьох попередніх варіацій $\xi$ значення для циклу Брайтона і для СНГ-стірлінга. Дані для $\mathrm{CO}_{2}$, отримані відповідно до (18), представлені в Таблиці 3. Для правильного порівняння, трьох циклів Брайтона, що працюють на НКФ/ $\mathrm{CO}_{2}$, нами були обрані 3 [5,6] варіанти 3 загальними обмеженнями: $\quad P_{\min }=P_{c}\left(\mathrm{CO}_{2}\right)=7.38 \quad$ МПа i $\eta_{T}=1-304.2 / 456.3=1 / 3$, але 3 різними $P_{\max }$ значеннями. Відповідний діапазон $\xi$-значень: $\xi^{B}\left(P_{\max }=10.92 \mathrm{MPa}\right)=1.24 ; \quad \xi^{B}\left(P_{\max }=14.17 \mathrm{MPa}\right)=1.46$, $\xi^{C S H}\left(P_{\max }=42.5 \mathrm{MPa}\right)=3.38$ демонструє очевидну перевагу СНГ-стірлінга. Роль ФТ2-області та іï гетерогенних станів у цій результуючій ефективності СНГ-стірлінга дуже важлива. Петля проміжного циклу Брайтона: 1-2-3-4-1 $3 \quad P_{\max }=14.17$ МПа показана на рис. 6 тонкими лініями зі стрілками для порівняння $з$ запропонованим СНГ-стірлінгом, зображеним жирними лініями на тій самій $(T, s)$-площині.

\section{5. Висновки}

ФТ-методологія $\epsilon$ спробою проаналізувати складні проблеми тепломасобміну покроково для будь-яких циклів 3 строго термодинамічної точки зору. Це поступово призводить до принципової відмінності між гіббсівським формулюванням 3 вілповідною термінологією квазі-рівноважних (або квазістатичних) процесів і ФТ-моделлю. Вона спирається на термодинамічне диференційне РС 3 рівнянь $(9,10)$ і на його наслідки для гетерогенних НКФстанів 3 рівняння (13). Точніше, введений в роботі критерій теплофізичної досконалості $\gamma^{F T}$ може бути легко представлений універсальними формами для теплового двигуна $(\mathrm{H})$ і теплового насоса $(\mathrm{C})$, відповідно:

$$
\gamma_{H}^{F T}=1-(\partial e / \partial s)_{T} /(\partial e / \partial s)_{v}=1-T_{i n t} / T^{G},
$$

$$
\gamma_{C}^{F T}=1-(\partial e / \partial v)_{T} /(\partial e / \partial v)_{s}=1+P_{i n t} / P^{G} .
$$

Рівняння Максвелла: $(\partial P / \partial T)_{v}=(\partial s / \partial v)_{T}$ було використане у формулі (20). Обидві гіббсівські визначення тут супроводжуються верхнім індексом $\mathrm{G}$ і випливають 3 локального термодинамічного потенціалу внутрішньої енергії $e(v, s) .3$ іншого боку, обидва ізотермічні наслідки $(20,21)$ повністю узгоджуються 3 формулюваннями Першого і Другого Закону для локальних динамічних змінних:

$$
\begin{gathered}
T_{i n t}=(\partial e / \partial s)_{T}, \\
P_{i n t}=(\partial e / \partial v)_{T} .
\end{gathered}
$$

Ізотермічний модуль об'ємного напруження $є$, безумовно, механічною властивістю, яка також визначається вищезазначеними динамічними змінними, включаючи притаманну ФТ-інтерпретацію питомої ентропії: $\Delta T s=\Delta T e / T_{i n t}[13]$ :

$$
\frac{\beta_{T}^{i g}}{\beta_{T}} \equiv \frac{1}{\rho k T \beta_{T}}=v^{2}\left\{\left[\frac{\partial^{2}\left(e / k T_{i n t}\right)}{\partial v^{2}}\right]_{T}-\left[\frac{\partial^{2}(s / k)}{\partial v^{2}}\right]_{T}\right\} \text {. }
$$

Ми застосували ФТ-методологію до НКФобласті як в цілому, так і до пропонованого СНГстірлінгу з цікавими і перспективними, на наш погляд, результатами.

\section{Література}

1. Rogankov, V.B. Fluctuational-thermodynamic interpretation of small angle $\mathrm{x}$-ray scattering experiments in supercritical fluids, Fluid Phase Equilibria 383 (2014) 115-125. https://doi.org/10.1016/j.fluid.2014.10.010

2. Rogankov, V.B., Levchenko, V.I. Global asymmetry of fluids and local singularity in the diameter of the coexistence curve, Phys.Rev.E 87, 052141 (2013). doi:https://doi.org/10.1103/physreve.87.052141

3. Rogankov, V.B., Shvets, M.V., Rogankov, O.V. Re-established congruent vapor-liquid diagram and fluctuation aspects of isotope theory- $\left(\mathrm{H}_{2} \mathrm{O}-\mathrm{D}_{2} \mathrm{O}-\mathrm{T}_{2} \mathrm{O}\right)$. Fluid Phase Equilibria. 485 (2019) 101 https://doi.org/ 10.1016/j.fluid.2018.12.012

4. Walker, G., Stirling Engines, Clarendon Press, Oxford, 1980. 
5. Chen, H., Goswami, D.Y., Stefanakos, E.K. A review of thermodynamic cycles and working fluids for the conversion of low-grade heat, Renewable and Sustainable Energy Reviews 14 (2010) 3059-3067.

6. Chen, Y., Lundquist, P., Johsnsson, A., Platell, P. A comparative study on the carbon dioxide transcritical power cycle compared with an organic Rankine cycle with R123 as working fluid in waste heat recovery, Applied Thermal Engineering 26 (2006) 2142-2147.
7. Wurm, J., Kinast, J.A., Roose, T.R., Staats, W.R. Stirling and Vuilleumeir heat pumps, McGraw-Hill Inc., NY,USA, 1990.

8. Woodcock, L.V. Thermodynamics of criticality: percolation loci, mesophases and a critical dividing line in binary-liquid and liquid-gas equilibria, Journal of Modern Physics 7 (2016) 760-773.

Отримана в редакції 27.02.2019, прийнята до друку 02.04.2019

\title{
Concept of the conjugated along the critical isochoric Stirling cycle, working on carbon dioxide
}

\author{
M. V. Shvets \\ Odessa National Academy of Food Technologies, 112 Kanatna str, Odesa, 65039, Ukraine
}

\begin{abstract}
The new concert to realize more effectively the well-known cycle of Stirling is proposed in the range of not only supercritical but also themselves critical temperature and pressure. The existence of such a heterogeneous stationary lattice nanostructure in sufficiently wide ranges of supercritical properties, which was called the nongibbsian phase of the fluid, was investigated (Rogankov. V.B and others) within the framework of the FT model (fluctuation thermodynamics). Such a fluid structure can be quite promising in practical use. It is based on the revealed by the model of Fluctuational Thermodynamics the existence of a heterogeneous non-gibbsian steady structure in the supercritical fluid region. The presence of the lattice-type local distributions in density and caloric properties was derived from the model of van-der-Waals applied to the consideration of mesoscopic nanoscales of volume. It seems as a type ot the known Stirling-Rallis engine which is the well-established tool to exploit the single-phase advantages on the working fluid. Ouraim is to increase the effectiveness of a cycle by the account of an special fluctuation the properties of a supercritical fluid just in the critical region. A new concept of the degree of thermophysical refinement (complemented by the accepted concept of thermodynamic perfection) was introduced in the work. The environmentally-isolated design of both sub-circles (I) and (II) and interconnecting stirling is its advantage over internal combustion cycles. Carbon dioxide is proposed as a potentially promising working substance. Thus, our goal is to use the detected nanodispersed fluid properties to formulate the concept of creating a conjugate, rather efficient Stirling cycle with a promising working substancesupercritical carbon dioxide instead of the traditional use of hydrogen or helium. In the total the proposed approach is directed to provide the enoiromentally-friendly designed thermel engine.
\end{abstract}

Keywords: regeneration and heat recovery, critical isochora, conjugated Stirling's cycle, heterogeneous supercritical region.

\section{References}

1. Rogankov, V.B. Fluctuational-thermodynamic interpretation of small angle $\mathrm{x}$-ray scattering experiments in supercritical fluids, Fluid Phase Equilibria 383 (2014) 115-125. https://doi.org/10.1016/j.fluid. 2014.10.010

2. Rogankov, V.B., Levchenko, V.I. Global asymmetry of fluids and local singularity in the diameter of the coexistence curve, Phys.Rev.E 87, 052141 (2013). doi:https://doi.org/10.1103/physreve.87.052141

3. Rogankov, V.B., Shvets, M.V., Rogankov, O.V. Re-established congruent vapor-liquid diagram and fluctuation aspects of isotope theory- $-\left(\mathrm{H}_{2} \mathrm{O}-\mathrm{D}_{2} \mathrm{O}-\mathrm{T}_{2} \mathrm{O}\right)$. Fluid Phase Equilibria. 485 (2019) 101 https://doi.org/ 10.1016/j.fluid.2018.12.012

4. Walker, G., Stirling Engines, Clarendon Press, Oxford, 1980.
5. Chen, H., Goswami, D.Y., Stefanakos, E.K. A review of thermodynamic cycles and working fluids for the conversion of low-grade heat, Renewable and Sustainable Energy Reviews 14 (2010) 3059-3067.

6. Chen, Y., Lundquist, P., Johsnsson, A., Platell, P. A comparative study on the carbon dioxide transcritical power cycle compared with an organic Rankine cycle with R123 as working fluid in waste heat recovery, Applied Thermal Engineering 26 (2006) 2142-2147.

7. Wurm, J., Kinast, J.A., Roose, T.R., Staats, W.R. Stirling and Vuilleumeir heat pumps, McGraw-Hill Inc., NY,USA, 1990.

8. Woodcock, L.V. Thermodynamics of criticality: percolation loci, mesophases and a critical dividing line in binary-liquid and liquid-gas equilibria, Journal of Modern Physics 7 (2016) 760-773. 